\title{
Electrochemical behavior of boron in LiF-NaF-KF- melts
}

Polyakova, L.P.; Bukatova, G.A.; Polyakova, E.G.; Christensen, Erik; Barner, Jens H. Von; Bjerrum, Niels

Published in:

Journal of The Electrochemical Society

Link to article, DOI:

10.1149/1.1837184

Publication date:

1996

Document Version

Publisher's PDF, also known as Version of record

Link back to DTU Orbit

Citation (APA):

Polyakova, L. P., Bukatova, G. A., Polyakova, E. G., Christensen, E., Barner, J. H. V., \& Bjerrum, N. (1996).

Electrochemical behavior of boron in LiF-NaF-KF- melts. Journal of The Electrochemical Society, 143(10), 31783186. https://doi.org/10.1149/1.1837184

\section{General rights}

Copyright and moral rights for the publications made accessible in the public portal are retained by the authors and/or other copyright owners and it is a condition of accessing publications that users recognise and abide by the legal requirements associated with these rights.

- Users may download and print one copy of any publication from the public portal for the purpose of private study or research.

- You may not further distribute the material or use it for any profit-making activity or commercial gain

- You may freely distribute the URL identifying the publication in the public portal 
3. K. Vinodgopal, S. Hotchandani, and P. V. Kamat, $J$. Phys. Chem., 97, 9040 (1993).

4. A. Hagfeldt, U. Björksten, and S. E. Lindquist, Sol. Energy Mater. Sol. Cells, 27, 293 (1992).

5. I. Bedja, S. Hotchandani, and P. V. Kamat, J. Phys. Chem., 98, 4133 (1994).

6. U. Björksten, J. Moser, and M. Grätzel, Chem. Mater. 6, 858 (1994).

7. S. Hotchandani and P. V. Kamat, This Journal, 139, $1630(1992)$

8. G. Hodes, I. D. J. Howell, and L. M. Peter, ibid., 139, $3136(1992)$

9. B. O'Regan, J. Moser, M. Anderson, and M. Grätzel, J. Phys. Chem., 94, 8720 (1990).

10. G. Redmond, D. Fitzmaurice, and M. Grätzel, Chem. Mater., 6, 686 (1994).

11. M. K. Nazeeruddin, A. Kay, I. Rodicio, B. R. Humphry, E. Mueller, P. Liska, N. Vlachopoulos, and M. Grätzel, J. Am. Chem. Soc., 115, 6382 (1993).

12. N. Alonso-Vante, J. F. Nierengarten, and J. P. Sauvage, J. Chem. Soc., Dalton Trans., 11, 1649 (1994).

13. A. Kay and M. Grätzel, J. Phys. Chem., 97, 6272 (1993).

14. D. Liu and P. V. Kamat, ibid., 97, 10769 (1993).

15. R. Vogel, P. Hoyer, and H. Weller, ibid., 98, 3183 (1994).

16. A. Ennaoui, $S$. Fiechter, $H$. Tributsch, M. Giersig, R. Vogel, and H. Weller, This Journal, 139, 2514 (1992).

17. R. Knödler, J. Sopka, F. Harbach, and H. W. Guenling, Sol. Energy Mater. Sol. Cells., 30, 277 (1993).

18. A. Hagfeldt, B. Didriksson, T. Palmqvist, H. Lindström, S. Södergren, H. Rensmo, and S.-E. Lindquist, ibid., 31, 481 (1994).
19. A. Hagfeldt and M. Grätzel, Chem. Rev., 95, 49 (1995).

20. R. Könenkamp, R. Henninger, and P. Hoyer, J. Phys. Chem., 97, $7328(1993)$

21. R. Könenkamp, A. Wahi, and P. Hoyer, Thin Solid Films, 246, 13 (1994).

22. S. Södergren, A. Hagfeldt, J. Olsson, and S. E. Lindquist, $J$. Phys. Chem., 98, 5552 (1994).

23. W. Gärtner, Phys. Rev., 116, 84 (1959).

24. M. A. Butler, J. Appl. Phys., 48, 1914 (1977).

25. S. E. Lindquist, B. Finnström, and L. Tegner, This Journal, 130, 351 (1983).

26. H. Lindström, H. Rensmo, A. Solbrand, S. Södergren and S.-E. Lindquist, J. Phys. Chem., 100, 3084 (1996).

27. S. E. Lindquist, A. Lindgren, and C. Leygraf, Sol. Energy Mater, 15, 367 (1987).

28. A. Hagfeldt, H. Lindström, S. Södergren, and S.-E. Lindquist, $J$. Electroanal. Chem., 381, 39 (1995).

29. T. A. Heimer, C. A. Bignozzi, and G. J. Meyer, J. Phys. Chem.., 97, 11987 (1993)

30. H. O. Finklea, Semiconductor Electrodes: Studies in Physical and Theoretical Chemistry, Vol. 55, Elsevier Science Publ., New York (1988).

31. S. E. Lindquist, A. Lindgren, and Y. Zhu, This Journal, 132, $623(1985)$

32. G. Rothenberger, D. Fitzmaurice, M. Grätzel, J. Phys. Chem., 96, 5983 (1992).

33. C. Gutierrez and P. Salvador, This Journal., 133, 924 (1986).

34. D. J. Fitzmaurice, M. Eschle, H. Frei, and J. Moser, $J$. Phys. Chem., 97, 3806 (1993).

\title{
Electrochemical Behavior of Boron in LiF-NaF-KF- Melts
}

\author{
L. P. Polyakova, G. A. Bukatova, and E. G. Polyakov \\ Institute of Chemistry, KSC RAS, Apatity, 184200 Russia
}

E. Christensen, J. H. von Barner, and N. J. Bjerrum*

Materials Science Group, Department of Chemistry, Technical University of Denmark, DK-2800 Lyngby, Denmark

\section{ABSTRACT.}

The electrochemical reduction of $\mathrm{B}(\mathrm{III})$ to $\mathrm{B}(0)$ in $\mathrm{KBF}_{4}-\mathrm{LiF}-\mathrm{NaF}-\mathrm{KF}$ melts has been studied by voltammetric and chronopotentiometric methods. Glassy carbon, $\mathrm{Pt}$, and Ag were used as working electrode materials. Only in the case of Ag was the reduction not complicated by interaction between boron and the electrode material. On a silver electrode B(III) was reduced to $\mathrm{B}(0)$ in a single irreversible step in the $\mathrm{KBF}_{4}$ concentration range up to $5.7 \times 10^{-2}$ mole percent $(\mathrm{m} / \mathrm{o})$. The cathodic half-wave potential was $-1.34 \mathrm{~V}$ vs. an $\mathrm{Ag} / \mathrm{AgCl}$ reference electrode at $700^{\circ} \mathrm{C}$. The diffusion coefficient of $\mathrm{BF}_{4}^{-}$at $700^{\circ} \mathrm{C}$ was determined to be $2.06 \times 10^{-5} \mathrm{~cm}^{2} \mathrm{~s}^{-1}$. Further increase of the $\mathrm{KBF}_{4}$ concentration above $5.7 \times 10^{-2} \mathrm{~m} / \mathrm{o}$ leads to a change in the reduction process. An ohmic resistance control becomes the limiting factor of the boron electroreduction process. The "apparent surface resistance" changes from 3.0 to $21.6 \Omega \mathrm{cm}^{2}$ as the temperature decreases from 700 to $550^{\circ} \mathrm{C}$, respectively. Furthermore at $\mathrm{KBF}_{4}$ concentrations higher than $5.7 \times 10^{-2} \mathrm{~m} / \mathrm{o}$ a second reduction peak and a corresponding anodic peak appeared on the voltammograms. These peaks were attributed to formation of alkali metal borides.

\section{Introduction}

Due to various unique physical and chemical properties, refractory metal borides have attracted increasing attention by researchers recently. ${ }^{1-17}$ Molten salts provide some possibilities for implementing a technology for refractory metal boride deposition either by using chemical reaction with the substrate ${ }^{1}$ or electrolysis. Two approaches of the latter method are available: (i) boron electrochemical deposition on a refractory metal substrate followed by diffusion into the metal phase ${ }^{2}$ or (ii) a direct electrochemical synthesis. The electrochemical synthesis has the advantage compared to the galvanodiffusion method, that the solid-state diffusion, which is often a rate-determining

* Electrochemical Society Active Member. step, is avoided. Further, it allows production not only of coatings but also powders. Most investigations ${ }^{3-17}$ on the electrochemical synthesis of refractory metal borides are concerned with development of coating technologies. Therefore more knowledge about the mechanism of the electrochemical deposition of boron and refractory metals is needed.

Unlike the electrochemistry of the refractory metals, the electrochemical behavior of boron is not clear. Investigations concerming the mechanism of the cathodic reduction of boron ions ${ }^{8-14,16,18-20}$ do not give a comprehensive idea of the mechanism and the kinetics of the boron electrodeposition. It was shown $\mathrm{n}^{9,10}$ for platinum electrodes that the reduction process $\mathrm{B}$ (III) $\rightarrow \mathrm{B}(0)$ proceeds reversibly in fluoride melts. However this reaction was shown by several authors to be irreversible at glassy carbon elec- 
trodes. ${ }^{12,15,20}$ These authors as well as others ${ }^{18,19}$ suggested that the process of boron(III) reduction in chloride-fluoride and fluoride melts proceeded in one step without the participation of intermediates, whereas in two other publication $\mathrm{s}^{21,22} \mathrm{~B}(\mathrm{II})$ ions are assumed to be formed according to the reaction $\mathrm{B}+2 \mathrm{~B}^{3+} \rightarrow 3 \mathrm{~B}^{2+}$. However no attempt was made to study the anodic dissolution of boron.

One fundamental problem in many electrochemical investigations of boron chemistry is the choice of indicator electrode material. In the literature one can find references to the use of a various materials for this purpose: iron, ${ }^{4}$ copper and graphite, ${ }^{6}$ platinum, ${ }^{9-11}$ tungsten, ${ }^{12}$ and glassy carbon. ${ }^{12,14,20}$ Platinum and glassy carbon have often been used but these materials are likely to form compounds with boron, for example the $\mathrm{B}-\mathrm{C}$ system formation of $\mathrm{B}_{4} \mathrm{C}$, $\mathrm{B}_{13} \mathrm{C}_{2}$, and $\mathrm{B}_{8} \mathrm{C}$ are known to take place. ${ }^{23}$ Clearly, a material that is inert with respect to boron is the most suitable substance for the investigation of the electrochemical behavior of boron. Certainly this material should also have a wide "electrochemical window." Further, it is difficult to compare the results obtained in different papers because of the various reference electrodes used.

Finally the purity of the solvent and other chemicals used to prepare the melts can also play an important role. In particular oxide contaminations are important in this connection since oxide ions react with $\mathrm{B}$ (III) forming oxofluoro-complexes of different kinds. The sources of oxide contamination are numerous: the solvent melts, the added complex fluorides, the inert gases when they are not properly purified, and oxide-containing materials of the cell elements.

Information on the purity of the electrolyte is of great significance since the presence of oxide ions in halide melts alters the mechanism of the electrode processes. This problem has been discussed recently. ${ }^{24,25}$ Mamantov and co-workers ${ }^{26}$ have proposed a reinvestigation of the old experimental data with regard to this factor.

Therefore we decided to investigate the electrochemical behavior of $\mathrm{KBF}_{4}$ dissolved in $\mathrm{LiF}-\mathrm{NaF}-\mathrm{KF}$ (46.5, 11.5, $42.0 \mathrm{~mol} \%$ ) eutectic melts (Flinak) with a carefull control of the oxide contents. Identification of the electrochemical reations was made by comparing the experimental data obtained with the different electrode materials.

\section{Experimental}

Linear voltammetry was used as the main experimental technique. For investigation of the interaction between deposited boron and the working electrode material, reverse chronopotentiometry was also used.

Equipment.-Electrochemical investigations were conducted with potentiostat PI50-1.1, programmer PR-8, and recording potentiometer PDA-1 plus a Schlumberger potentiostat Model 1286 with a Hewlett Packard X-Y recorder. The three-electrode electrochemical cell applied in the experiments as well as the other experimental procedures has been described previously. ${ }^{24}$ The glassy carbon vessel used to contain the melt also served as counterelectrode (CE).

Chemicals.- $\mathrm{KBF}_{4}$ (pure grade from Aldrich) was recrystallized according to Cantor et al ${ }^{27}$ Then, in a glove box with an argon atmosphere, it was pressed into pellets and stored in hermetically sealed polyethylene containers. $\mathrm{Na}_{2} \mathrm{O}$ was prepared by heating $\mathrm{Na}_{2} \mathrm{O}_{2}$ (analytical grade from Merck) in an alumina crucible under vacuum at $600^{\circ} \mathrm{C}$ for $12 \mathrm{~h}$. Analysis by titration with hydrochloric acid gave 98 weight percent (w/o)

The Flinak solvent was prepared from analytical grade $\mathrm{LiF}, \mathrm{NaF}$, and $\mathrm{KF}$, that were purified either by recrystallization from the melt (with cooling rate $3^{\circ} \mathrm{C} / \mathrm{h}^{2 B}$ ) or by zone refining. As a result of such treatment, the alkali metal fluorides contained at least one order of magnitude less oxide ions than in the case of prolonged evacuation followed by electrolysis with graphite electrodes. The alkali fluorides were kept in hermetically sealed containers. Careful preparation of the salts was performed to pre- vent formation of boron oxofluoro-complexes in the melts. The oxide ion concentration in our experiments was determined by a linear voltammetry method with a glassy carbon working electrode that has been described previously. ${ }^{29}$

Reference electrode.-It is traditionally difficult to find an acceptable reference electrode for fluoride melts. An obvious choice would be a reference electrode with a diaphragm made of an insoluble fluoride, however Brookes et $a l .{ }^{4}$ mentioned that a $\mathrm{Ni} / \mathrm{Ni}^{2+}$ reference electrode with a diaphragm of a lanthanum fluoride single crystal did not work satisfactorily in a Flinak- $\mathrm{KBF}_{4}$ melt at temperatures higher than $550^{\circ} \mathrm{C}$.

Some materials applied for the reference electrodes may react with the melt and in this way give rise to formation of undesired electrochemically active species. For instance electrode designs involving diaphragms made of oxidecontaining materials, ${ }^{30}$ such as applied by Taranenko et $a l .{ }^{12}$ and Kushkhov et $a l .^{15}$ are not sufficiently protected from the electrolyte. These authors ${ }^{12.15}$ used a silver reference electrode immersed in a sealed quartz tube without a protecting graphite shell, when studying $\mathrm{NaCl}-\mathrm{KCl}-\mathrm{KBF}_{4}$ melts with sodium fluoride additions.

Wendt et $a l^{6}{ }^{6}$ applied a platinum quasi-reference electrode (QRE) in an eutectic melt of lithium, potassium, and sodium fluorides but the potentials were referred to the sodium equilibrium potential determined using a copper "dynamic reference electrode" (based on the oxidation of the copper working electrode). In our opinion, this method is questionable because the potential at which the anodic dissolution of copper is initiated depends both on temperature and polarization rate.

In the same work, in studies of chloride-fluoroborate melts, a "dynamic chlorine reference electrode" (not separated from the electrolyte by a diaphragm) was used. This was a somewhat unfortunate choice, because even minor amounts of fluoride ions, according to Nekrasov, ${ }^{31}$ leads to a change in the electrode function of such a dynamic reference electrode, for example freon evolution on graphite with a marked depolarization preceding the oxidation of chloride ions on it. Moreover, the presence of such a strong oxidizing agent as $\mathrm{Cl}_{2}$ in the electrolyte may affect complex formation and redox equilibria.

A comparison of the experimental data is complicated (if possible at all) because of the variety and nonreliability of the reference electrodes.

Thus the problem of proper reference electrodes for fluoride and chloride-fluoride melts remains open. The use of QREs, with all their simplicity and convenience in operation, may be regarded only as a temporary solution because they provide a random electrode potential that may be changed both with changes in the melt composition (e.g., $\mathrm{KBF}_{4}$ or $\mathrm{Na}_{2} \mathrm{O}$ introduction) and temperature. In any case such data cannot be considered a reliable basis for exact thermodynamical calculations.

In our study we applied platinum, silver, and glassy carbon (GC) as QREs. The potentials of all the studied materials had close values and good reproducibility in melts with constant composition. However, in some experiments, the more reliable $\mathrm{Ag} / \mathrm{AgCl}(2 \mathrm{w} / \mathrm{o}$ in equimolar $\mathrm{NaCl}-\mathrm{KCl}$ ) reference electrode $(\mathrm{Ag} / \mathrm{AgCl}-\mathrm{RE})$ was also used. ${ }^{24}$ The potential of this electrode remained constant for several days. The melt is only in direct contact with glassy carbon and a graphite diaphragm. Molten mixtures of $\mathrm{AgCl}-$ $\mathrm{NaCl}-\mathrm{KCl}$ was used as an electrolyte for the reference electrode. This reference electrode seems to be one of the most reliable. The design should give little risk of oxide contamination of the electrolyte. However we must point out the existence of a diffusion potential due to the use of a chloride-based reference electrode, but since the ionic surroundings do not change much during our experiments it is reasonable to assume that the diffusion potential will be almost constant. However, the design of this reference electrode has some weak points. For example, an alumina tube in the hot zone above the melt ${ }^{24}$ may in longer experiments serve as a source of melt contamination due to cor- 
rosion caused by vapors from the electrolyte. Therefore we usually did not use the $\mathrm{Ag} / \mathrm{AgCl}$ reference electrode for such experiments. The difference of potentials between GC-QRE and $\mathrm{Ag} / \mathrm{AgCl}-\mathrm{RE}$ at $700^{\circ} \mathrm{C}$ was 0.55 to $0.56 \mathrm{~V}$.

Working electrode.-The working electrodes made of boron, glassy carbon, silver, or platinum rods (diam 0.29 to $1.50 \mathrm{~mm}$ ) were immersed 10 to $15 \mathrm{~mm}$ into the melt with the aid of a micrometer screw.

\section{Results and Discussion}

Figure 1 shows typical voltammograms of solvent electrolyte (Flinak) obtained with glassy carbon and silver working electrodes. They are characterized by very weak waves caused by oxidation of residual oxide ions. With a glassy carbon working electrode, these waves are located in the potential region 0.3 to $0.6 \mathrm{~V}$ vs. $\mathrm{Ag} / \mathrm{AgCl}-\mathrm{RE}$ (Fig. 1a) or between 0.85 and $1.15 \mathrm{~V}$ vs. GC-QRE (Fig. 1b).

The oxide ion concentration in the background electrolyte could be calculated on the basis of linear voltammetry data by methods described by Polyakova et al. ${ }^{32}$ In a previous article ${ }^{29}$ we showed that in the Flinak- $\mathrm{K}_{2} \mathrm{TaF}_{7^{-}}$ $\mathrm{Na}_{2} \mathrm{O}$ melt the concentration dependence of the anodic peak current corresponding to oxidation of oxide ions was linear. Thus such a plot was used to obtain the residual concentration of oxide ions in the Flinak solvent melts. This procedure is not completely correct, since one must assume that the slopes of the plot of the anodic peak current $v s$. the oxide concentration $\left(I_{\mathrm{p}}^{\mathrm{a}}-\mathrm{C}_{\mathrm{O}^{2}-}\right.$ plots $)$ in the Flinak- $\mathrm{Na}_{2} \mathrm{O}$ and Flinak- $\mathrm{K}_{2} \mathrm{TaF}_{7}-\mathrm{Na}_{2} \mathrm{O}$ melts are equal.

To obtain more precise data, a titration of the Flinak melt with $\mathrm{Na}_{2} \mathrm{O}$ was performed. As is seen from the $I_{\mathrm{r}}^{a}-\mathrm{C}_{\mathrm{O}^{2}-}$ plot (Fig. 2) the background melt contains $1.5 \times 10^{-3} \mathrm{~m} / \mathrm{o}$ oxide ions. Usually in our experiments values in the range (1-3) $\times 10^{-3} \mathrm{~m} / \mathrm{o}$ were found for different solvent melts. Alkali metal reduction at glassy carbon (Fig. 1d) proceeds with depolarization compared to the situation with a silver working electrode (Fig.1c). This is probably due to intercalation of the alkali metal into the glassy carbon.

Unfortunately, in numerous publications $s^{4,8,8-14}$ dealing with boron electrochemistry, the voltammograms of the solvent melt are either not given at all ${ }^{4,8-10,12-14}$ or given at low current sensitivity ${ }^{6,11}$ which makes the evaluation of

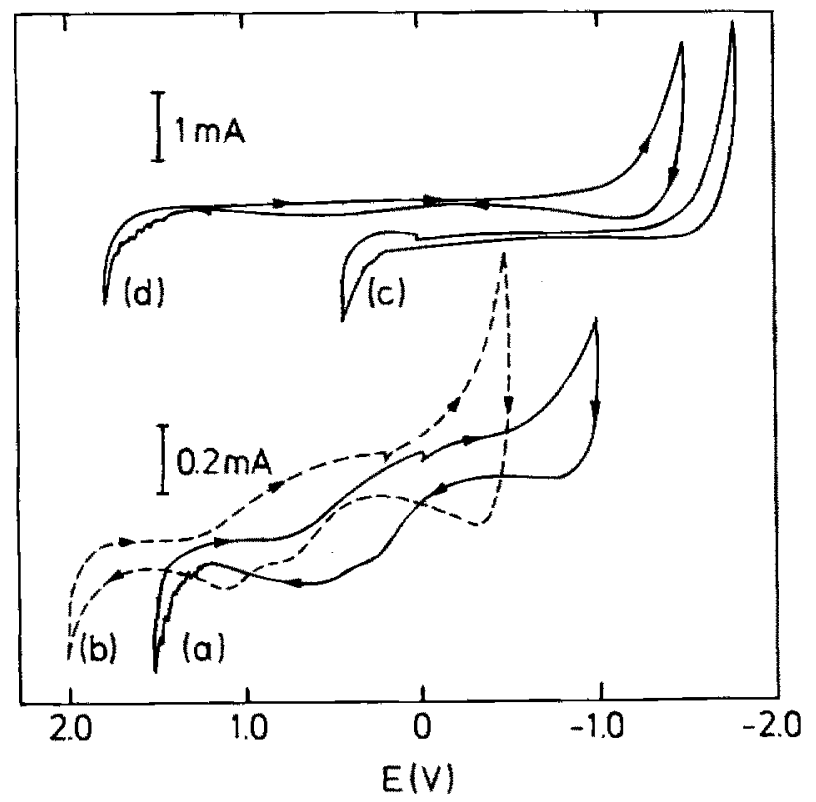

Fig. 1. Linear sweep voltammograms of Flinak background melt, oxide ion concentration $\mathrm{C}=2.4 \times 10^{-3} \mathrm{~m} / \mathrm{o}, \mathrm{T}=700^{\circ} \mathrm{C}$, scan rate $0.1 \mathrm{~V} \mathrm{~s}^{-1}$. Ag/ $\mathrm{AgCl}$ reference electrode: (a, d) glassy carbon (GC) working electrode, $A_{G C}=0.22 \mathrm{~cm}^{2}$ (different current scales) (c) Ag working electrode, $A_{A_{g}}=0.47 \mathrm{~cm}^{2}$. GC-QRE: (b) GC working electrode, $A_{G C}=0.22 \mathrm{~cm}^{2}$. The small dents in the voltammograms indicate the starting points (with zero current).

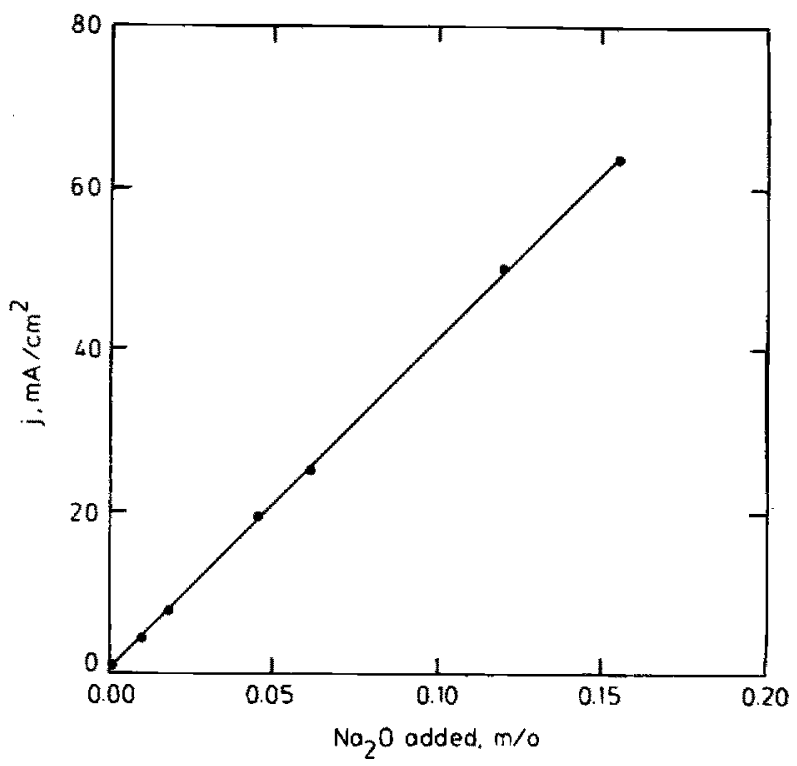

Fig. 2. Anodic current density of $\mathrm{O}^{2-}$ oxidation peaks as a function of $\mathrm{O}^{2-}$ concentration in Flinak- $\mathrm{Na}_{2} \mathrm{O}$ melt, $\mathrm{T}=600^{\circ} \mathrm{C}$, scan rate $0.1 \mathrm{Vs}^{-1}$

the oxide ions concentration in the starting electrolyte difficult. No proper information can be derived from a voltammogram obtained at a metal working electrode, for instance, at copper ${ }^{6}$ since this metal dissolves at more negative potentials than the potential at which the oxide ions are oxidized. However, in the work of Wendt et al. ${ }^{8}$ the solvent melt was prepared from dried analytical grade alkali metal fluorides. From other investigations performed in our laboratories we know that the use of such chemicals may typically give an oxide impurity level up to $1.0 \mathrm{~m} / \mathrm{o}$.

Analysis of published data and our own preliminary experiments have shown the importance of a correct selection of working electrode materials to study the electrochemical behavior of boron. Makyta et al. ${ }^{9}$ investigated the behavior of platinum, tungsten, silver, glassy carbon, and tantalum as working electrodes. They considered platinum as being the most reliable material. They also observed the appearance of a peak in the voltammograms caused by interaction between platinum and boron being deposited in accordance with the phase diagram of the B-Pt system. ${ }^{33}$

Wendt et al,, ${ }^{8}$ who used graphite and copper working electrodes, explained the appearance of additional anodic peaks by dissolution of boron carbides and copper-boron alloys formed under cathodic polarization of these electrodes in boron containing melts. Taranenko et al. ${ }^{12}$ claimed that they did not observe formation of boron carbides on glassy carbon electrodes. However according to Kuzma and Chaban ${ }^{23}$ formation of $\mathrm{B}_{4} \mathrm{C}, \mathrm{B}_{13} \mathrm{C}_{2}$, and $\mathrm{B}_{8} \mathrm{C}$ took place in the B-C system. There are a lot of experimental data on iron boride formation on an iron cathode, for instance, $\mathrm{FeB}$ and $\mathrm{Fe}_{2} \mathrm{~B}$ have been detected. ${ }^{4}$

According to Kuzma and Chaban ${ }^{23}$ and Polyakov et al., ${ }^{34}$ silver does not react with boron and has a wide "electrochemical window." In addition we have conducted experiments that should permit a reliable evaluation of the interaction of the electrode material with the substances deposited during the process of cathodic polarization. Besides silver, the behavior of platinum and glassy carbon as indicator electrodes was studied. This made it possible to compare our results with previously published data.

In our case we applied a constant current for a fixed period of time $\left(\tau_{c}\right)$. Subsequently the potential decay was followed at zero current (open-circuit potential decay). The appearance of steps on the potential decay curve indicated the presence of intermetallics in the deposits being dissolved. A slow potential decay (instead of an expected potential drop) is characteristic of solid solutions. ${ }^{35}$ 


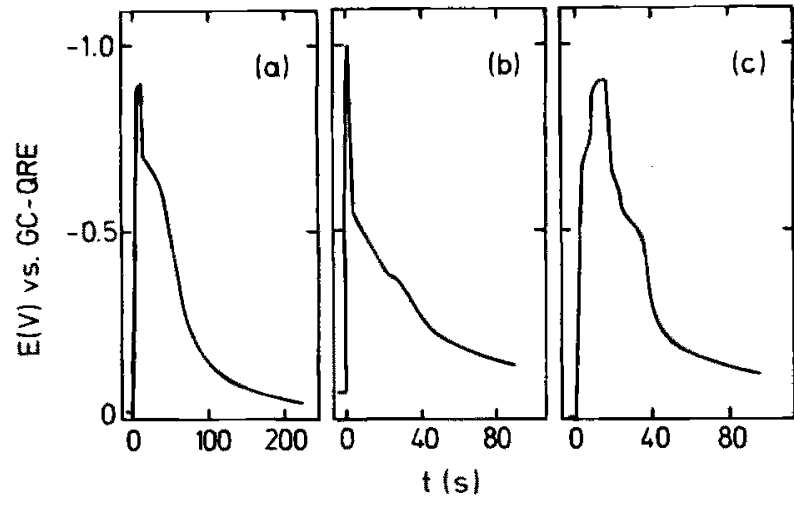

Fig. 3. Open-circuit potential decay Flinak- $\mathrm{KBF}_{4}$ melt, $T=600^{\circ} \mathrm{C}$, GC-QRE. (a) Ag electrode, $i=1.64 \mathrm{~mA} \mathrm{~cm}^{-2}, \tau_{\mathrm{c}}=7 \mathrm{~s}$. (b) Pt electrode, $j_{k}=33.3 \mathrm{~mA} \mathrm{~cm}^{-2}, \tau_{\mathrm{s}}=2$ s. (c) GC electrode, $j_{k}=2.38 \mathrm{~mA}$ $\mathrm{cm}^{-2}, \tau_{\mathrm{c}}=15 \mathrm{~s}, \mathrm{C}_{\mathrm{KBF} / \mathrm{A}}=15.9 \times 10^{-2} \mathrm{~m} / \mathrm{o}$.

Figure 3 presents the anodic potential-time decays for the three electrodes obtained in a Flinak- $\mathrm{KBF}_{4}$ melt at $600^{\circ} \mathrm{C}$. Each of the curves is characterized by a plateau associated with boron dissolution. The most pronounced is found at the silver electrode in the potential region -0.65 to $-0.70 \mathrm{~V}$ ( vs. a glassy carbon QRE). If the potentials were measured $v s$. a boron electrode (monofilament $\mathrm{O}=0.29$ $\mathrm{mm}$, Goodfellow), these plateaus corresponded to zero potential. When the dissolution of the boron deposit is completed, the silver electrode potential drops quickly approaching the stationary potential value of silver in this melt asymptotically. Such shape of the curves corresponds to a comparatively narrow region of solid solution which fits the data of Crespo et $a l^{36}$ In contrast to silver, platinum, and glassy carbon, besides solid solutions, form chemical compounds with boron. On $E$ - $t$ curves (Fig. 3b, c) plateaus due to dissolution of these compounds are seen. If we take into account, that the melt temperature in our experiments is only $600^{\circ} \mathrm{C}$, we can assume that the interaction between elementary boron (produced by reduction of $\mathrm{BF}_{4}^{-}$) and platinum, glassy carbon and other electrode materials will be more pronounced at $700^{\circ} \mathrm{C}$ (a usual working temperature).

A voltammetric study of the same melt with platinum and glassy carbon electrodes has confirmed the conclusions made on the basis of chronopotentiometric data. When a platinum electrode is used (Fig. 4c), two cathodic peaks occur in the voltammograms. The first corresponds to formation of $\mathrm{PtB}$. The potential of this reaction was independent on the scan rate. The anodic section of the first peak crossed the current axis at zero current without bending. This is characteristic of reversible processes and in agreement with the data of Matiasovsky et al. ${ }^{8}$ and Makyta et $a l^{11}$ (also obtained with the use of a platinum working electrode). The shape of the anodic curve (overpotential value) is different from the shape of the boron dissolution anode curve at a silver electrode (Fig. 4a). The reasons for such a striking contrast are discussed.

The second cathodic peak with a potential close to the boron discharge potential on silver $( \pm 10 \mathrm{mV})$ corresponds to the $\mathrm{B}(\mathrm{III}) \rightarrow \mathrm{B}(0)$ reduction on a platinum boride substrate. The difference between the first and the second cathodic peak potential is associated with depolarization due to alloy formation. This difference is $0.49 \mathrm{~V}$. Poorly reproducible distortions of the voltammograms are observed in boron reduction on glassy carbon electrodes (Fig. 4b), particularly when the temperature increases.

In Flinak- $\mathrm{KBF}_{4}$ melts in which boron is present as $\mathrm{BF}_{4}^{-}$ complexes, ${ }^{37}$ the shape of the voltammogram obtained with a silver working electrode depends on the $\mathrm{KBF}_{4}$ concentration, the temperature and the potential scan rate. At concentrations below $5.7 \times 10^{-2} \mathrm{~m} / \mathrm{o}$ one cathodic peak is observed (Fig. 5a) at $-1.46 \mathrm{~V}$ vs. Ag/AgCl-RE. An anodic

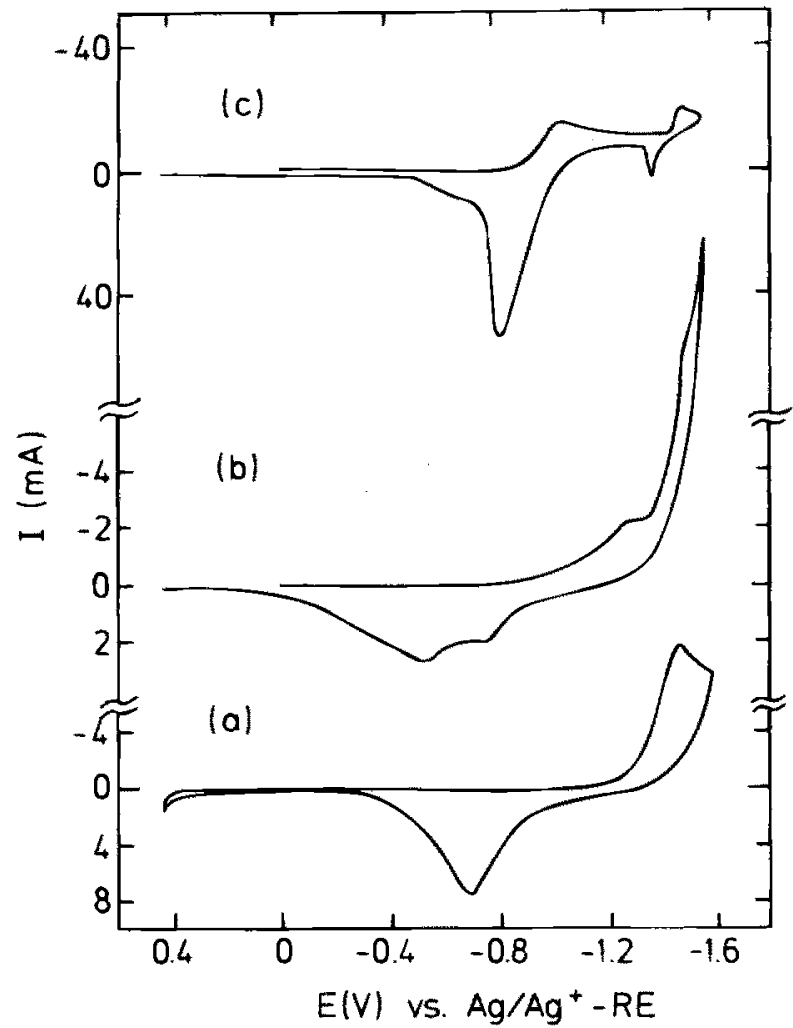

Fig. 4. Cyclic voltammograms of Flinak- $\mathrm{KBF}_{4}, T=700^{\circ} \mathrm{C}$, scan rate $0.1 \mathrm{~V} \mathrm{~s}^{-1}, \mathrm{Ag} / \mathrm{AgCl}$ reference electrode. (a) $\mathrm{Ag}$ electrode, $\mathrm{A}_{\mathrm{Ap}}$ $=0.47 \mathrm{~cm}^{2}, C_{\mathrm{kar}_{4}}=5.7 \times 10^{-2} \mathrm{~m} / \mathrm{o}$. (b) $G C$ electrode, $A_{\mathrm{cc}}=0.21$ $\mathrm{cm}^{2}, C_{\mathrm{KBF}}=14.2 \times 10^{-2} \mathrm{~m} / \mathrm{o}$. (c) Pt electrode, $A_{\mathrm{pt}}=0.05 \mathrm{~cm}^{2}, C_{\mathrm{KBF} / 4}$ $=12.0 \times 10^{-2} \mathrm{~m} / \mathrm{o}$.
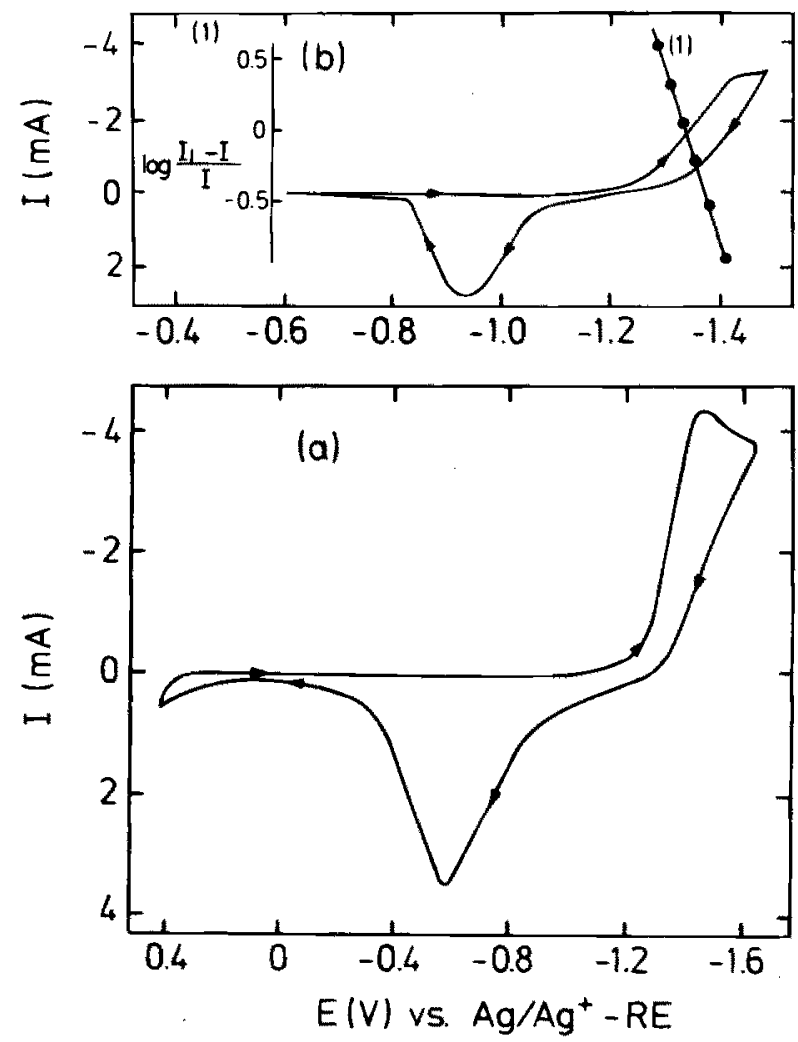

Fig. 5. Cyclic voltammograms of Flinak-KBF, $\left(2.6 \times 10^{-2} \mathrm{~m} / 0\right)$ melt, $T=700^{\circ} \mathrm{C}, \mathrm{Ag}$ electrode, $A_{\mathrm{g}}=0.47 \mathrm{~cm}^{2}$. Scan rate $\left(\mathrm{V} \mathrm{s}^{-1}\right)$ : (a) $0.1 ;$ (b) 0.005 . (i) $\log (i-n / I$ vs. $E$. 
peak corresponding to dissolution of the deposited substance (proceeding under an overpotential of $0.87 \mathrm{~V}$ ) is also observed. The cathodic half-wave potential on the quasi-steady-state curve (Fig. $5 \mathrm{~b}$ ) vs. $\mathrm{Ag} / \mathrm{AgCl}$ is $-1.34 \mathrm{~V}$. The cathodic deposit obtained on the silver electrode at the same potential is elementary boron, according to $x$-ray and spectral analysis.

Diagnostics of the one stage $\mathrm{B}(\mathrm{III}) \rightarrow \mathrm{B}(0)$ reduction process was conducted by well-known criteria ${ }^{38}$ as described. From the experimental data (Table I) a plot of the peak current $\left(I_{\mathrm{pc}}\right)$ vs. the square root of the scan rate $\left(v^{1 / 2}\right)$ can be obtained. Such a plot gives a linear dependence. The peak potential depends linearly on the logarithm of the sweep rate, that is a tenfold increase of $v^{1 / 2}$ brings about a $60 \mathrm{mV}$ shift of the cathode peak. The theoretical value of this shift for an irreversible process is $1.15 R T / \alpha n F^{39}$ Based on $n=3$ and assuming $\alpha=0.5$ we obtain the calculated value $59 \mathrm{mV}$ which is in agreement with the experiment, and confirms the assumption of irreversibility of boron reduction in the melt.

The peak current obtained in the potassium fluoroborate concentration region (1.2 to 5.7$) \times 10^{-2} \mathrm{~m} / \mathrm{o}$ increases linearly with concentration, whereas the peak potential does not depend on it. This also confirms the irreversible character of the cathode process accompanying solidphase deposition on the electrode.

Reversibility of the process can be easily and reliably determined by using equations linking the peak width of the voltammograms with the number of electrons participating in the act of charge-transfer. Thus for a reversible reduction with the formation of a product soluble in the melt or in the electrode material, Eq. 1 is valid ${ }^{39}$

$$
E_{\mathrm{p} / 2}-E_{\mathrm{p}}=2.2 R T / n F
$$

In reversible reduction with formation of insoluble substance Eq. 2 applies $^{40}$

$$
E_{\mathrm{p} / 2}-E_{\mathrm{p}}=0.77 R T / n F
$$

Generally, for irreversible cathodic processes, i.e., both for soluble and insoluble products, this difference of potentials becomes ${ }^{41,42}$

$$
E_{\mathrm{p} / 2}-E_{\mathrm{p}}=1.857 R T / \alpha n F
$$

The first of these equations is universal and may be applied to both cathode and anode processes. Equations 2 and 3 are true only for reduction processes whose anodic curve parameters depend on the quantity of substance deposited in the cathodic part of the cycle.

In the equations given above, $E_{\mathrm{p} / 2}$ is the half-peak potential, $E_{\mathrm{p}}$ is the peak potential, $\alpha_{\mathrm{p}}$ is the transfer coefficient, and $n$ is the number of electrons participating in chargetransfer. In our experiments, the difference between peakand half-peak potential at $700^{\circ} \mathrm{C}$ in the scan rate range 0.05 to $1.0 \mathrm{~V} \mathrm{~s}^{-1}$ was $96 \mathrm{mV}$. The cathodic reduction proceeded with reduced solid substance formation, therefore in the calculations only Eq. 2 and 3 were used. According to Eq. $2, n=0.67$ whereas $\alpha n$, determined from Eq. 3

Table I. Current and potential data for boron deposition on a silver electrode at $700^{\circ} \mathrm{C}$ and $\mathrm{KBF}_{4}$ concentration $2.6 \times 10^{-2} \mathrm{~m} / \mathrm{o}$ in molten Flinak, $A_{A g}=0.47 \mathrm{~cm}^{2}$.

\begin{tabular}{cccccc}
\hline $\begin{array}{c}\nu \\
\left(\mathrm{mV} \mathrm{s}^{-1}\right)\end{array}$ & $\begin{array}{c}I_{\mathrm{pc}} \\
(\mathrm{mA})\end{array}$ & $\begin{array}{c}E_{\mathrm{pc}}^{\mathrm{a}} \\
(\mathrm{V})\end{array}$ & $\begin{array}{c}E_{\mathrm{pc} / 2}^{\mathrm{a}} \\
(\mathrm{V})\end{array}$ & $\begin{array}{c}E_{\mathrm{pc}}^{\mathrm{b}} \\
(\mathrm{V})\end{array}$ & $\begin{array}{c}\alpha n \\
(\mathrm{Eq} .3)\end{array}$ \\
\hline 50 & 3.0 & -1.445 & -1.350 & -0.895 & 1.64 \\
100 & 4.2 & -1.461 & -1.365 & -0.910 & 1.62 \\
200 & 5.9 & -1.482 & -1.387 & -0.930 & 1.64 \\
250 & 6.7 & -1.487 & -1.391 & -0.940 & 1.62 \\
400 & 8.5 & -1.497 & -1.400 & -0.950 & 1.60 \\
500 & 9.3 & -1.505 & -1.409 & -0.955 & 1.62 \\
1000 & 12.9 & -1.521 & -1.421 & -0.970 & 1.56
\end{tabular}

${ }^{a} E_{\mathrm{pc}}$ and $E_{\mathrm{pc} / 2}$ are $v s . \mathrm{Ag} / \mathrm{AgCl}$ reference electrode.

${ }^{\mathrm{b}} E_{\mathrm{pc}}$ is $v s$. GC-QRE. yields the value 1.62 (Table I). Taking into account that the process $\mathrm{B}(\mathrm{III})+3 e \rightarrow \mathrm{B}(0)$ is a one-stage process, we determined $\alpha=0.54$. The equations mentioned above allow us to classify the boron reduction process under our experimental conditions as irreversible, and to calculate the value of the diffusion coefficient of its fluoride complexes from Eq. 4 accoding to Delahay ${ }^{38}$

$$
I_{\mathrm{p}}=0.496 n F C A D^{1 / 2}(\alpha n F V / R T)^{1 / 2}
$$

Using the density value $1.99 \mathrm{~g} \mathrm{~cm}^{-3}$ for Flinak-melt at $700^{\circ} \mathrm{C}$, calculated on the basis of the work by Blander et $a l .^{43}$ the diffusion coefficient of the boron fluorocomplexes at $700^{\circ} \mathrm{C}$ is $2.06 \times 10^{-5} \mathrm{~cm}^{2} \mathrm{~s}^{-1}$.

For stationary voltammograms (Fig. 5b), Frumkin plot appears to be linear: $E-\log \left(I_{t}-I\right) / I$ which is characteristic for an irreversible process. ${ }^{44}$ The slope of this plot, 2.3 $R T / \alpha n F$, allowed us to calculate $\alpha=0.67$. This value of $\alpha$ is somewhat larger than the value determined by linear voltammetry, but this is expected because the polarographic reversibility depends on the sweep rate. ${ }^{45}$

When the $\mathrm{KBF}_{4}$ concentration is increased (beyond $5.7 \times$ $10^{-2} \mathrm{~m} / \mathrm{o}$ ) the shape of the voltammogram changes (Fig. 6). The addition of fluoroborate causes both the growth of the earlier observed peak (Fig. 6a) and the appearance of a new one at more negative potentials (Fig. $6 \mathrm{~b}$ ). The changes became noticeable 1 to $2 \mathrm{~min}$ after the addition and stablization was obtained after 30 to $40 \mathrm{~min}$. During this period the first peak becomes less distinguished, predominating the second peak (Fig. 6c). The two peaks practically merge in one, with a height which is larger than expect-

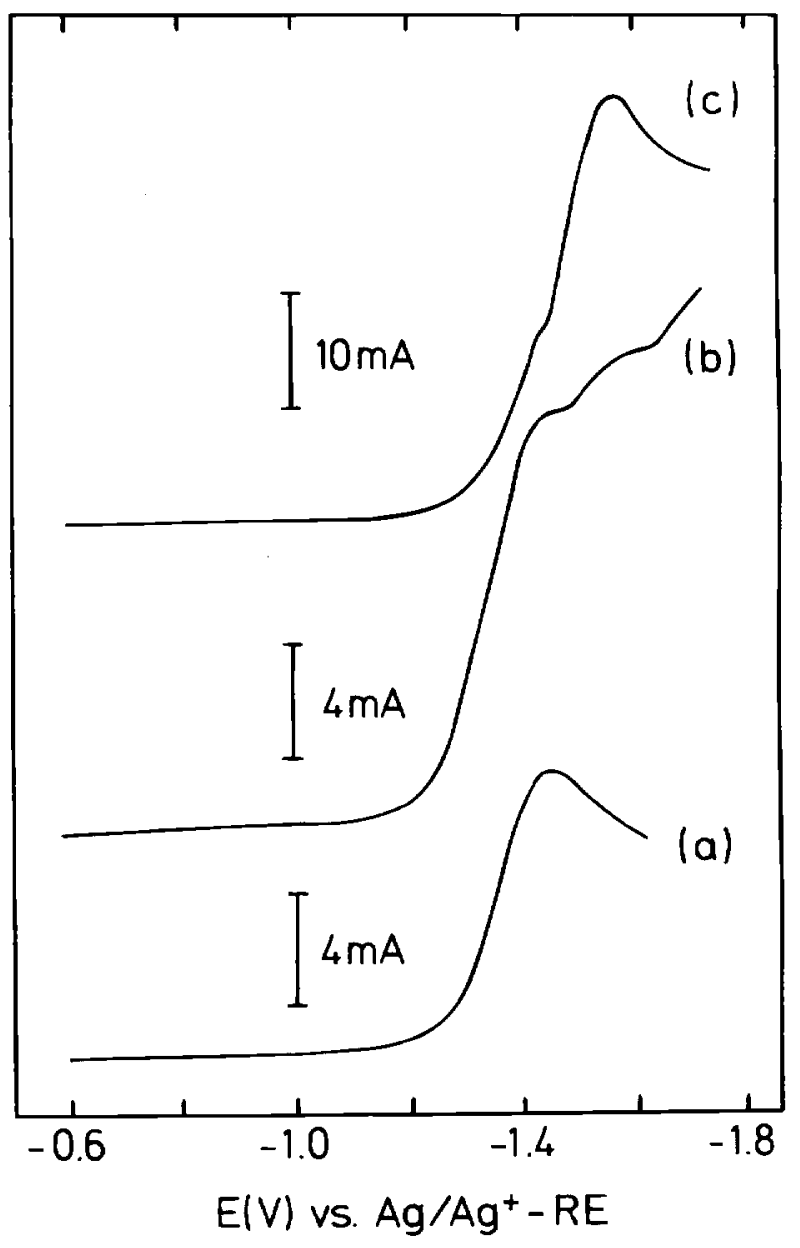

Fig. 6. Variation of voltammogram shape vs. $\mathrm{KBF}_{4}$ concentration $T=700^{\circ} \mathrm{C}$, scan rate $0.1 \mathrm{~V} \mathrm{~s}^{-1}, A_{A}=0.47 \mathrm{~cm}^{2}$. (a) $C_{\mathrm{KBF}_{4}}=5.7 \times$ $10^{-2} \mathrm{~m} / 0$. (b) $C_{\mathrm{XBF}}=12.1 \times 10^{-2} \mathrm{~m} / 0(2 \mathrm{~min}$ after addition). (c) $C_{\mathrm{KBF}_{4}}=12.1 \times 10^{-2} \mathrm{~m} / \mathrm{o}$ ( $30 \mathrm{~min}$ after addition). 
ed in comparison with the previous addition. At higher $\mathrm{KBF}_{4}$ concentrations, the first wave seemed not to change. Only the second peak grows. Two peaks are also observed in the anodic section of the voltammetric curve (Fig. 7). However, when the concentration of $\mathrm{KBF}_{4}$ is larger than $5.7 \times 10^{-2} \mathrm{~m} / \mathrm{o}$, reproducibility of the anodic curve is unsatisfactory. Besides embrittleness, growth of the working electrode area can be observed after polarization, particularly at low sweep rates when the reverse potential reached potentials of the second limiting current plateau.

The dark deposit, produced by potentiostatic electrolysis at potentials corresponding to the second cathodic wave could not be identified by $\mathrm{x}$-ray analysis.

In the course of the entire experiment we controlled the oxide ion content in the melt, to be sure that the second peak is not associated with discharge of boron oxofluoro complexes. The total $\mathrm{O}^{2-}$ concentration in the melt characterized by the voltammogram on Fig. $6 \mathrm{a}$ is equal to $2.4 \times$ $10^{-3} \mathrm{~m} / \mathrm{o}$; the $\mathrm{O} / \mathrm{B}$ molar ratio $\approx 0.042$. When the $\mathrm{KBF}_{4}$ content achieves the value of $12 \times 10^{-2} \mathrm{~m} / \mathrm{o}$ (Fig. $6 \mathrm{~b}, \mathrm{c}$ ) the $\mathrm{O} / \mathrm{B}$ molar ratio decreases to 0.02 . Therefore the effect of the oxygen content in the melt on the shape of voltammograms observed is negligible. It is impossible to calculate the number of electrons participating in this electrode process. The very steep slope of the ascending voltammogram section in the mixed kinetics region points either to a multielectron (10 or more electrons) discharge or to a complication in the mechanism of the electrode process.

However we can assume a coreduction of boron and alkali metal ions at these potentials. It is known that even during electrorefining when the applied cathodic current densities are lower than during electrowinning the content of alkali metal in boron may reach values as high as 3 to 4 w/o. ${ }^{46}$ The appearance of new anodic peaks in the potential region between alkali metal and boron dissolution (Fig. 7), may then be explained by the presence of alkali metal-boron compounds in the deposit. This conclusion fully coincides with the data of Kellner, ${ }^{47}$ who studied $\mathbf{B F}_{3}$ reduction in the LiF-KF melt at a copper working electrode. Using chemical analysis he established that increase in the cathodic current density results in a significant reduction of the boron content in the cathodic deposit. At the same time, spectral analysis showed that in these samples potassium was present as a major impurity. ${ }^{47}$ The author did not give any rigorous interpretation of his only voltammogram, but he concluded that it was likely that a small amount of potassium was deposited along with the boron at all potentials, while increasing amounts were deposited at more negative potentials.

Reduction of the polarization rate and temperature leads to a better separation of the first and second peaks.

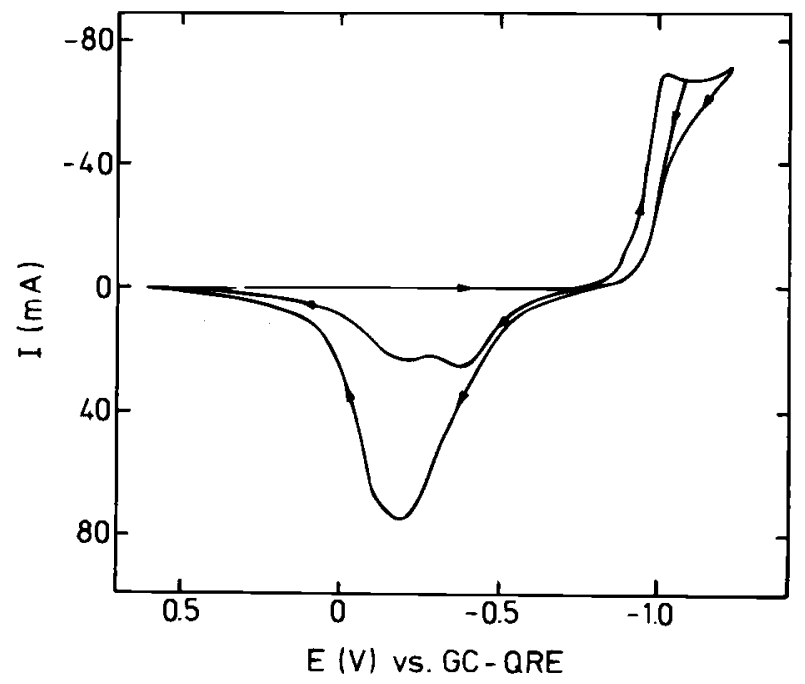

Fig. 7. Cyclic voltammogram of Flinak-KBF $4\left(12.1 \times 10^{-2} \mathrm{~m} / \mathrm{o}\right)$ melt, $T=700^{\circ} \mathrm{C}$, scan rale $0.1 \mathrm{~V} \mathrm{~s}^{-1}, A_{A_{g}}=0.47 \mathrm{~cm}^{2}$.
Therefore in the subsequent experiments we used the scan rate range 0.05 to $5.0 \mathrm{mV} \mathrm{s}{ }^{-1}$ at $700^{\circ} \mathrm{C}$, and used higher rates at lower temperatures. Figure 8 shows typical steady-state voltammograms of Flinak- $\mathrm{KBF}_{4}$ melts at 700 and $550^{\circ} \mathrm{C}$. Their shape can be explained by the formation of a highly resistive layer on the electrode surface as described below. To obtain reproducible curves similar to those of Fig. 8, the working electrode must be activated by polarization at potentials close to the silver dissolution potential preliminary to the recording of the voltammograms. The reproducibility becomes better after switching off polarization at more positive potentials than the second wave potentials. High reproducibility was featured by multisweep voltammograms limited by the first peak potential in the cathodic region.

As is seen in Fig. 9 the sweep rate increase causes the broadening of the cathodic peaks, but the separation of the first peak and the rising branch of the second peak at $600^{\circ} \mathrm{C}$ remains satisfactory. When the temperature is increased, the first and second peaks overlap even at low polarization rates. Reduction peak broadening mainly occurs due to the ohmic control of the boron deposition process. This conclusion is in agreement with the linear plots of peak current and peak potential against the square root of the polarization rate (Fig. $10 \mathrm{a}, \mathrm{b})$ this agrees with the theory of a surface film formation under

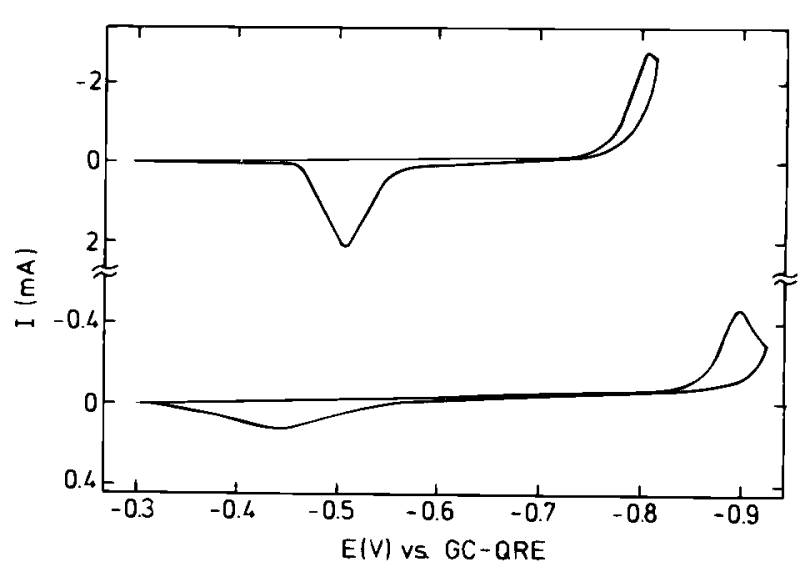

Fig. 8. Stationary voltammograms of Flinak- $\mathrm{KBF}_{4}$ melt. Scan rate $1.0 \mathrm{mV} \mathrm{s}^{-1}, A_{\mathrm{Ag}_{\mathrm{g}}}=0.61 \mathrm{~cm}^{2}$. $C_{\mathrm{KBF}_{4}}=15.9 \times 10^{-2} \mathrm{~m} / \mathrm{O}, T$ ( $\left.{ }^{\circ} \mathrm{C}\right)$ : (a) 700 , (b) 550 .

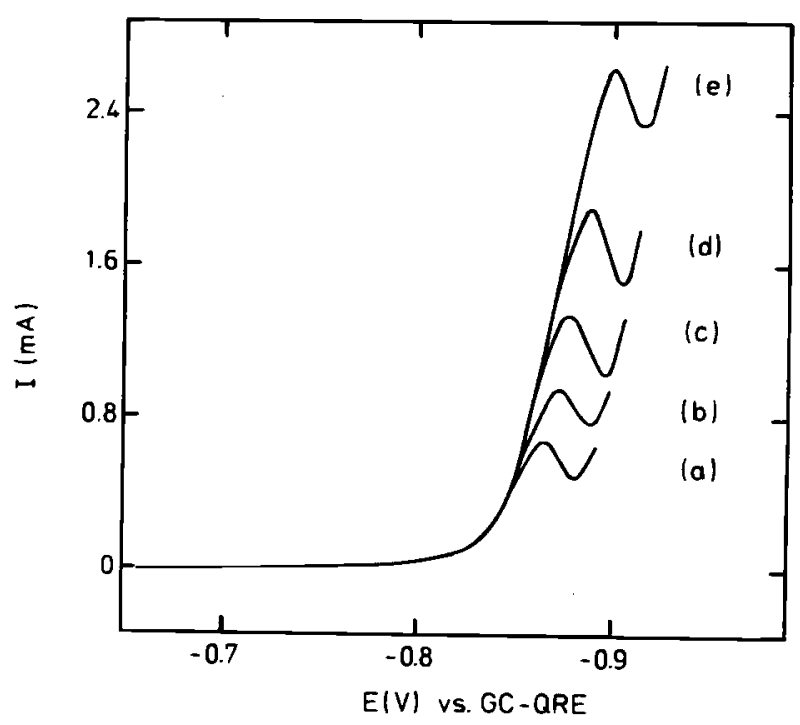

Fig. 9. Effect of scan rate on cathodic peak broadening in Flinak$\mathrm{KBF}_{4}\left(15.9 \times 10^{-2} \mathrm{~m} / 0\right)$ melt, $T=600^{\circ} \mathrm{C}, A_{A_{g}}=0.61 \mathrm{~cm}^{2}$. Scan rate $\left(m V s^{-1}\right):$ (a) 0.5 , (b) 1.0, (c) 2.5, (d) 5.0, and (e) 10.0 . 

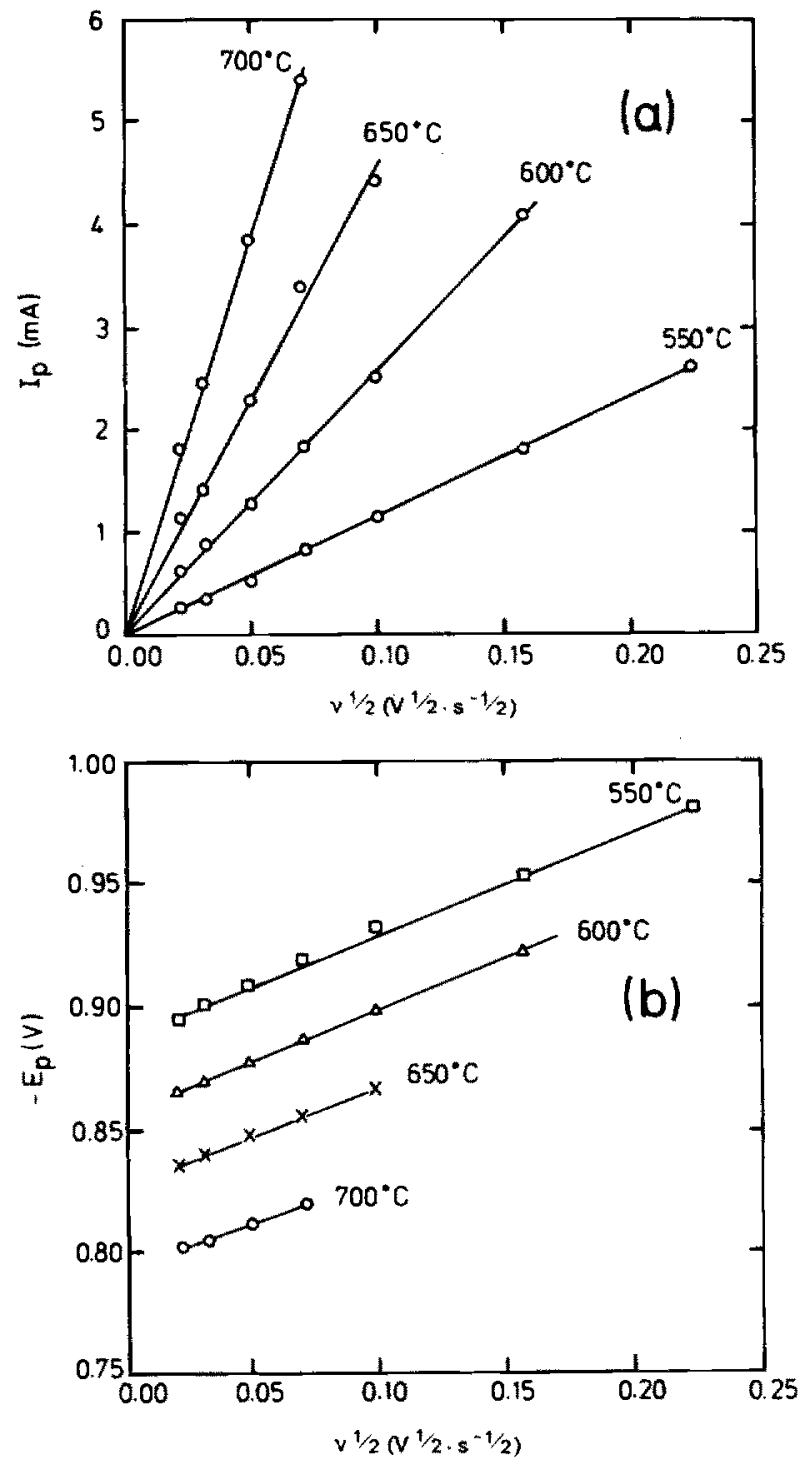

Fig. 10. Sweep rate effect on (a) peak current and (b) peak potential of the $\mathrm{BF}_{4}^{-}$reduction process. $C_{\mathrm{KBF}_{4}}=15.9 \times 10^{-2} \mathrm{~m} / \mathrm{o}, A_{A_{3}}=$ $0.61 \mathrm{~cm}^{2}$.

ohmic resistance control ${ }^{48-50}$ Coefficients of equations corresponding to these dependences

$$
\begin{gathered}
E_{\mathrm{p}}=a+b v^{1 / 2} \\
I_{\mathrm{p}}=c v^{1 / 2}
\end{gathered}
$$

are given in Table II.

The "apparent surface resistance" of the electrolyte in the pores of the boron film covering the electrode was obtained from the slope of the lines in coordinates $j_{\mathrm{p}}-E_{\mathrm{p}}$ (Fig. 11). It can also be calculated from Eq. $7^{50}$

$$
R_{\mathrm{app}}=\left(E_{\mathrm{p}}-a\right) / I_{\mathrm{p}}=b / c
$$

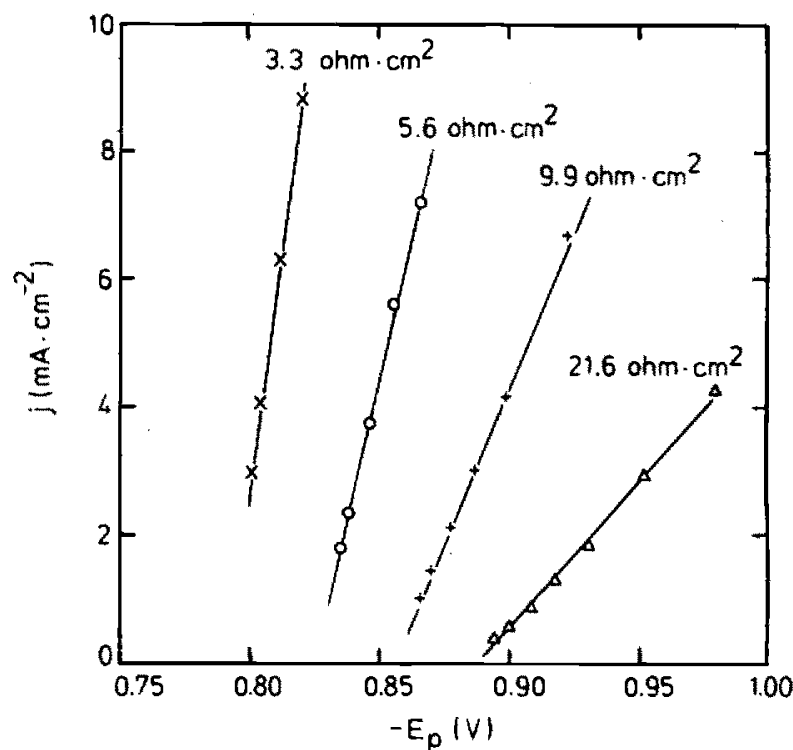

Fig.11. Peak current density vs, peak potential from the cyclic voltammograms of a flinak-KBF ${ }_{4}$ melt, $C_{\mathrm{KBF}_{4}}=15.9 \times 10^{-2} \mathrm{~m} / \mathrm{o}$ (calculations are made on the basis of Fig. $10 \mathrm{a}, \mathrm{b}) .(\mathrm{x}) 700^{\circ} \mathrm{C},(\mathrm{o})$ $650^{\circ} \mathrm{C},\left(+1600^{\circ} \mathrm{C},(\triangle) 550^{\circ} \mathrm{C}\right.$.

Figure 11 demonstrates the dependence of the apparent surface resistance on temperature. In the range of 550 to $700^{\circ} \mathrm{C}$ it changes from 21.6 to $3.3 \Omega \mathrm{cm}^{2}$.

The nucleation potentials were obtained from linear extrapolation of the leading edges of the cathodic and anodic peaks to zero current ${ }^{51}$ (Fig. 12). The cathodic and anodic nucleation overpotentials were calculated as the difference between the equilibrium potential and the nucleation potentials. The boron equilibrium potential was defined either by using a boron rod electrode (Fig. 12a) or from the voltammetric data obtained by applying a very narrow potential scan range ${ }^{51}$ (Fig. 13). As is seen from Fig. 12a and Fig. 13 the values of the boron rod electrode equilibrium potential and the equilibrium for the boron coatings are very close.

The experimental data including nucleation potentials and nucleation overpotentials are given in Table III.

\section{Conclusion}

The mechanism of the electrochemical reduction of $\mathrm{BF}_{4}^{-}$ ions in Flinak depends on the concentration. At concentrations lower than $5.7 \times 10^{-2} \mathrm{~m} / \mathrm{o}, \mathrm{B}(\mathrm{III})$ is reduced to $\mathrm{B}(0)$ in a single irreversible step. At higher concentrations an ohmic resistance control obscures the kinetics of the cathodic process. The apparent surface resistance of the boron film being formed decreases when the temperature increases in agreement with the electrical properties of boron.

\section{Acknowledgment}

L. Polyakova and E. Polyakov are grateful to the Mads

\begin{tabular}{|c|c|c|c|}
\hline$T\left({ }^{\circ} \mathrm{C}\right)$ & $a(\mathrm{~V})$ & $b(\mathrm{~V})$ & $c\left(\mathrm{~A} \mathrm{~s}^{1 / 2} \mathrm{~V}^{-1 / 2}\right)$ \\
\hline $\begin{array}{l}700 \\
650 \\
600 \\
550\end{array}$ & $\begin{array}{r}-0.794 \pm 5.3 \times 10^{-5} \\
-0.826 \pm 2 \times 10^{-4} \\
-0.857 \pm 2 \times 10^{-3} \\
-0.887 \pm 5 \times 10^{-3}\end{array}$ & $\begin{array}{r}-0.360 \pm 2.1 \times 10^{-7} \\
-0.411 \pm 2.6 \times 10^{-7} \\
-0.413 \pm 1 \times 10^{-6} \\
-0.412 \pm 1 \times 10^{-5}\end{array}$ & $\begin{array}{r}75.599 \pm 1.4 \times 10^{-2} \\
44.416 \pm 5.8 \times 10^{-2} \\
25.522 \pm 6 \times 10^{-3} \\
11.637 \pm 2 \times 10^{-3}\end{array}$ \\
\hline
\end{tabular}
Clausens Foundation for financial support and personally

Table Il. Variation of peak potential ${ }^{\circ}$ and peak current ${ }^{b}$ with $v^{1 / 2}\left(\mathrm{KBF}_{4}\right.$ concentration $\left.15.9 \times 10^{-2} \mathrm{~m} / \mathrm{o}\right)$.

${ }_{\mathrm{p}}^{\mathrm{a}}=a+b v^{1 / 2}$

${ }^{b} i_{p}=c v^{1 / 2}$. 


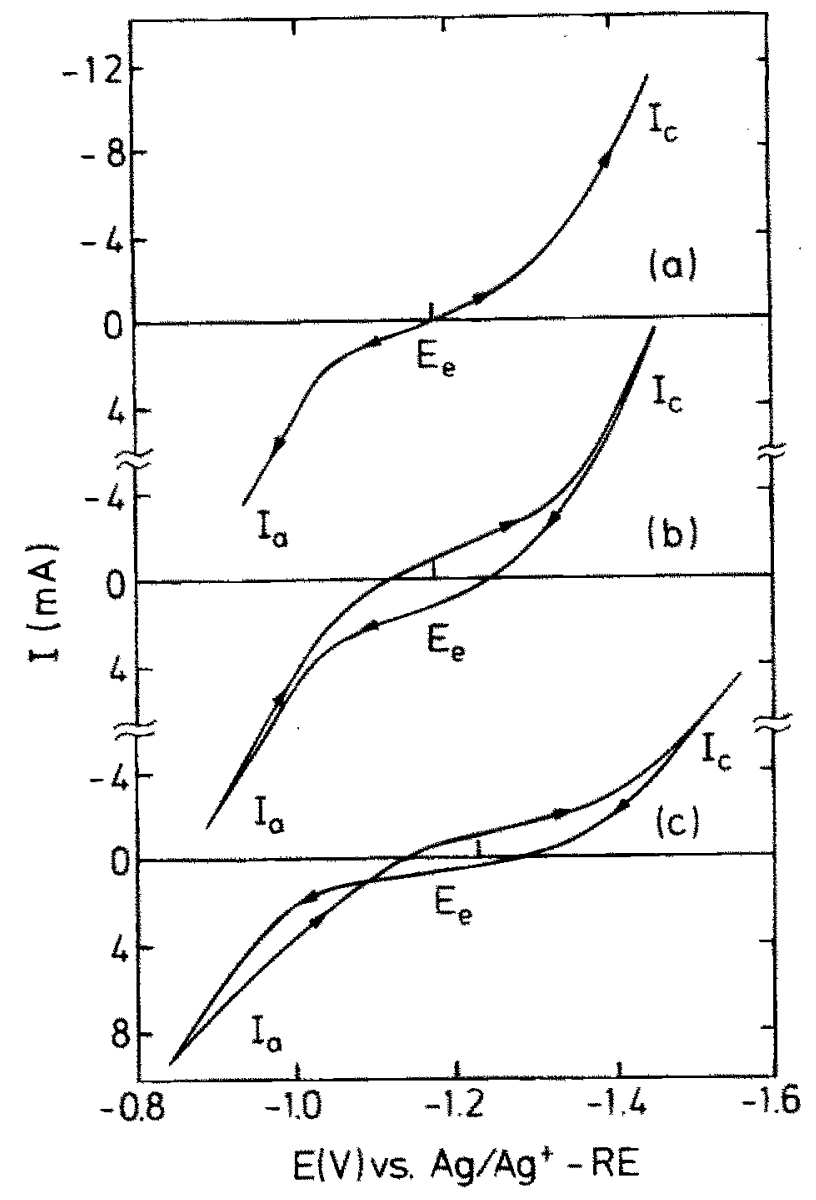

Fig. 12. Cyclic voltammograms of a Flinak-KBF $414.2 \times$ $10^{-2} \mathrm{~m} / \mathrm{o}$ ) mell obtained on a boron electrode, scan rate $5.0 \mathrm{mV}$ $\mathrm{s}^{-1}, A_{\mathrm{B}}=0.36 \mathrm{~cm}^{2}, T\left({ }^{\circ} \mathrm{C}\right):[\mathrm{a}, \mathrm{b}) 700,(\mathrm{c}) 600$.

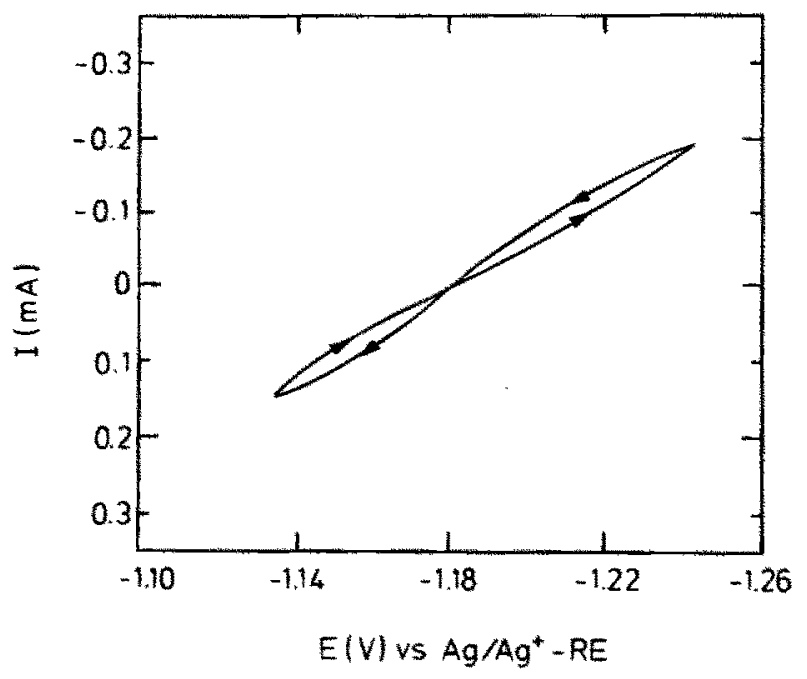

Fig. 13. Cyclic voltammograms of a Flinak- $-\mathrm{KBF}_{4} \| 14.2 \times$ $10^{-2} \mathrm{~m} / 0$ ) melt in the range near the boron equilibrium potential, $T=700^{\circ} \mathrm{C}$, scan rate $5.0 \mathrm{mV} \mathrm{s}^{-1}, A_{B}=0.09 \mathrm{~cm}^{2}$.

to $H$. J. Pedersen and J. Christensen for having made their stay possible at Technical University of Denmark. Further thanks are due to Danish Natural Science Research Council. I. Petrushina is thanked for valuable discussions.

Manuscript submitted Oct. 16, 1995; revised manuscript received June 20,1996 .
Table Ill. Equilibrium potentials, nucleation potentiais, and overpolentials for $\mathrm{B}^{3} / \mathrm{B}$ redox couple in Flinak- $\mathrm{KBF}_{4}$ melt $\left(14.2 \times 10^{-2} \mathrm{~m} / \mathrm{o}\right) ; T=700^{\circ} \mathrm{C}$

\begin{tabular}{|c|c|c|c|c|c|}
\hline $\begin{array}{l}\text { Indicator } \\
\text { electrode }\end{array}$ & $\begin{array}{c}\text { Anodic } \\
\text { nucleation } \\
\text { potential } \\
\text { (mV) }\end{array}$ & $\begin{array}{l}\text { Cathodic } \\
\text { macleation } \\
\text { potential } \\
\text { (mV) }\end{array}$ & $\begin{array}{c}\text { Equilibrium } \\
\text { potential } \\
\text { (mV) }\end{array}$ & $(\mathrm{mV})$ & $(\mathrm{mV})$ \\
\hline $\begin{array}{l}\mathrm{B}^{\mathrm{a}} \\
\mathrm{Ag}^{\mathrm{a}} \\
\mathrm{Ag}\end{array}$ & $\begin{array}{r}-1080 \pm 5 \\
-1105 \pm 5 \\
-556 \pm 5\end{array}$ & $\begin{array}{r}-1295 \pm 5 \\
-1318 \pm 5 \\
-768 \pm 5\end{array}$ & $-1180 \pm 5$ & 100 & 115 \\
\hline
\end{tabular}

a Potentials vs. Ag/AgCl reference electrode.

Potentiais vs. GC-QRE.

\section{REFERENCES,}

1. N. G. Iyushchenko, A. I. Anfinogenov, A. F. Plotnitrova, and G. I. Belyaeva, Method of metals and alloys boriding, USSR Inventor's Certificate 206, 270. Cl.48B, 8/10, Bull. Izobret, No, 24 (1967).

2. N. C. Cook, Sci. Am., 221, 38 (1969).

3. G. W. Mellors and S. Senderoff, This Journal, 113, 60 (1966).

4. H. C. Brookes, P. S. Gibson, G. H. Hills, N. Narayan, and A. Wigley, Trans. Inst. Met. Finish., 54, 191 (1976).

5. $\mathrm{H}$ Wendt $\mathrm{K}$ Reuhl, and $\mathrm{T}$. Hom, Abstract in Third International Symposium on Molten Salt Chemistry and Technology, M. Chemla, D. Devilliers, and M. Vogler, Editors, Paris, 79(3) (1991).

6. H. Wendt, K. Reuhl, and V. Schwarz, Electrochim. Acta, 37, 237 (1992).

7. H. Wendt, K. Reuhl, and V. Schwarz, J. Appl. Electrochem., 22, $161(1992)$.

8. K. Matiasovsky, K. Grjotheim, and M. Makyta, Metal, 42, $1196(1988)$

9. M. Makyta, K. Matiasovsky, and P. Fellner, Electro chim. Acta, 29, 1653 (1984).

10. M. Makyta, M. Chrenkova, P. Fellner, and K. Matiasovm sky, Z. Anorg. Allg. Chem., 540/541, 169 (1986).

11. M. Makyta, K. Matiasovsky, and V. I. Taranenko, Electrochim. Acta, 34, 861 (1989).

12. V. I. Taranenko I. V. Zarutskii, V. I. Shapoval, M Makyta, and K. Matiasovsky, ibid., 37, 263 (1992).

13. V. I. Taranenko, V. A. Bidenko, I. V. Zarutskii, and S. V. Devyatkin, Boridy, Kiev, ISBN, p. 54 (1990).

14. S. V. Deviatkin, V. I. Taranenko, Kh. B. Kushkhov, and V. I. Shapoval, Rasplavy, 2, 71 (1992).

15. Kh. B. Kushkhov, V. V. Malyshev, A. A. Tishehenko, and V. I. Shapoval, Por. Met., 1, 8 (1993).

16. A. Bonomi, H. Giess, and C. Gentaz, Electrodeposition Surf. Treat., 1, $419(1972 / 73)$.

17. A. Bogacz, P. Los, W. Szklarski, and J. Josiak, Rudy Met. Niezelaz, 28, 134 (1983)

18. O. V. Chemezov, L. E. Ivanovskiy, and V. P. Batukhtin, Visokotemper. Fiz. Khim. i Elektrokhim. Trans. 3d Ural Konf., Sverdlovsk, p. 143 (1981).

19. S. V. Deviatkin, G. Kaptay, V. I. Shapoval, and E. Berecz, in Molten Salt Chemistry and Technology, M. L. Saboungi and $H$. Kojima, Editors, PV 93-9, p. 584, The Electrochemical Society Proceedings Series, Pennington, NJ (1993).

20. S. A. Kuznetsow, S. V. Deviatkin, and A. L. Glagolevskaya, Rasplavy, 2, 79 (1992).

21. N. G. Ilyushchenko, A. I. Anfinogenov, G. I. Belyaeva, in Zharostoik. Teplostoik. Pokryt. Trans. 4th Vsesojuzn. Sov. Zharostoik. Pokryt., Nauka, Lenin grad, p. $105(1969)$.

22. $\mathrm{T}$ Oki, in Proceedings of the Joint International Symposium on Molten Salts, Kyoto, p. 765 (1987).

23. Yu. B. Kuzma and N. F. Chaban, Binary and Termary Boron-Containing Systems, Metallurgiya, Moskow (1990).

24. L. P. Polyakova, E. G. Polyakov, A. I. Sorokin, and P. T. Stangrit, J. Appl. Electrochem., 22, 628 (1992).

25. E. G. Polyakov and P. T. Stangrit, Rasplavy, 2, 17 (1993).

26. K. D. Sienerth, E. M. Mondrogiannis, and G. Mamantov, This Journal, 141, 1762 (1994)

27. S. Cantor, D. P. McDermott, and L. O. Gilpatrick, $J$ Chem. Phys., 52, 4600 (1970). 
28. E. Christensen, X. Wang, J. H. von Barner, T. Østvold, and N. J. Bjerrum, This Journal, 141, 1213 (1994).

29. L. P. Polyakova, E. G. Polyakov, F. Matthiesen, E Chrstensen, and N. J. Bjerrum, ibid., 141, 2982 (1994).

30. A. F. Alabyshev, M. F. Lantratov, and A. G. Morachevskiy, Reference Electrodes for Molten Salts, Metallurgiya, Moskow (1965).

31. V. N. Nekrasov, D.Sci. (Chem.) Thesis., Sverdlovsk (1986).

32. L. P. Polyakova, Z. A. Kononova, I. R. Elizarova, and E. G. Polyakov, Zh. Anal. Khim., 49, 1228 (1994)

33. R. Naslain, Boron and Refractory Borides, V. I. Matkovich, Editor, p. 191, Springer, Berlin (1977).

34. E. G. Polyakov and P. T. Stangrit, Issled. Fiziko-khim. Svoistv Soed. Redk. Elem, Nauka, Leningrad, p. 111 (1978).

35. B. N. Kabanov, I. I. Astakhov, and I. G. Kiseleva, Kinet. Slozhn. Elektrokhim. React., Nauka, Moskow (1981).

36. A. J. Crespo, L.-E. Tergenius, and T. Lundstrom, $J$. Less-Common Met., 77, 147 (1981).

37. J. B. Bates and A. S. Quist, Spectrochim. Acta, 31A, $1317(1975)$

38. P. Delahay, New Instrumental Methods in Electrochemistry, Interscience, New York (1954).
39. A. J. Bard and L. R. Faulkner, Electrochemical Methods: Fundamentals and Applications, Wiley, New York (1980).

40. G. Mamantov, D. L. Manning, and J. M. Dale, $J$. Electroanal. Chem., 9, 253 (1965).

41. H. Matsuda and Y. Ayabe, Z. Elektrochem., 59, 494 (1955).

42. V. A. Golovin and G. A. Dobrenkov, Trans. Kazan. Khim.-Tekhnol. Inst., 34, 202 (1965).

43. M. Blander, W. R. Grimes, N. V. Smith, and G. M. Watson, J. Phys. Chem., 63, 1164 (1959),

44. Ya. Geirovskiy and Ya. Kuta, Principles of Polarography, Academic Press, New York (1966).

45. Z. Galus, Fundamentals of Electrochemical Analysis, Ellis Harwood Ltd., Chichester (1976).

46. D. R. Stern, This Journal, 107, 441 (1960).

47. J. D. Kellner, ibid., 120, 713 (1973).

48. A. J. Calandra, N. R. de Tacconi, and A. J. Arvia, Electrochim. Acta, 19, 901 (1974)

49. D. D. Macdonald, Transient Techniques in Electrochemistry, Plenum Press, New York (1977).

50. D. D. Macdonald and B. Roberts, Electrochim. Acta, 23, 781 (1978).

51. S. K. Preto, Z. Tomczuk, S. von Winbush, and M. F. Roche, This Joumal, 130, 264 (1983).

\title{
Investigation of Alkali Carbonate Transport Toward the Catalyst in Internal Reforming MCFCs
}

\author{
R. J. Berger, E. B. M. Doesburg, and J. G. van Ommen \\ Laboratory of Inorganic Chemistry, Materials Science and Catalysis, Faculty of Chemical Technology, \\ University of Twente, Enschede, The Netherlands
}

\author{
J. R. H. Ross
}

Department of Chemical and Environmental Sciences, University of Limerick, Ireland

ABSTRACT

A nickel catalyst to be used for internal steam reforming in a molten carbonate fuel cell (MCFC) must be resistant to the alkali components ( $\mathrm{Li}$ and $\mathrm{K}$ species) of the electrolyte; these components can reach the catalyst from the anode by either transport via the vapor phase or by means of surface creep along the walls. In a series of experiments for determining the rates of transport, it was found that the amount of alkali transported by creep along a metallic wall (Au or Ni) was much smaller than that transported via the vapor phase. The vapor transport occurred by the formation of the alkali hydroxides. The vapor pressure of LiOH was found to be eight times larger than that calculated from thermodynamic data. All the Al-containing materials tested strongly took up alkali from the gas phase. The catalysts $\mathrm{Ni} / \mathrm{MgO}$ and $\mathrm{Ni} / \mathrm{SiO}_{2}$ sintered strongly during exposure to gaseous $\mathrm{LiOH}$ and $\mathrm{KOH}$

\section{Introduction}

The molten carbonate fuel cell (MCFC), operating at $923 \mathrm{~K}$ can be fed directly with natural gas instead of hydrogen, if it is coupled with a catalytic steam-reforming system. The highest efficiency is obtained if the catalyst is positioned in the anode compartment of the fuel cell (i.e., internal reforming, IR-MCFC). The electrolyte is composed of a porous $\mathrm{LiAlO}_{2}$ tile filled with a molten eutectic mixture of $\mathrm{Li}_{2} \mathrm{CO}_{3}$ and $\mathrm{K}_{2} \mathrm{CO}_{3}$ [62 mole percent (m/o) $\left.\left.\mathrm{Li}_{2} \mathrm{CO}_{3}, 38 \mathrm{~m} / \mathrm{o} \mathrm{K}_{2} \mathrm{CO}_{3}\right)\right]{ }^{1}$

The poisoning of the steam-reforming catalyst by alkali from the electrolyte has been investigated at the Institute of Gas Technology ${ }^{2}$ and by several other authors. ${ }^{3-5}$ The rates of deactivation of reforming catalysts in the presence of alkali, reported in literature, ${ }^{2-5}$ vary widely according to the experimental conditions. The transport mechanism of alkali carbonates under MCFC conditions therefore needs

a Present address: Laboratory for Chemical Technology Eindhoven University of Technology, $5600 \mathrm{MB}$ Eindhoven, The Netherlands.

b Present address: ECN, Materials Science, Petten, The Netherlands. closer attention; however, literature concerning this subject is very scarce. From thermobalance experiments, Ong and Claar ${ }^{6}$ concluded that loss of $\mathrm{Li}_{2} \mathrm{CO}_{3}$ and $\mathrm{K}_{2} \mathrm{CO}_{3}$ in $\mathrm{H}_{2} \mathrm{O} / \mathrm{CO}_{2}$ mixtures occurs mainly as a result of the formation and vaporization of the corresponding alkali hydroxides.

This paper reports the results of experiments in which the rate of transport of alkali via the vapor phase as well as that by surface creep have been measured. It also describes the effect of alkali on the steam-reforming behavior of a number of catalysts.

The two ways in which movement of alkali toward the catalyst in the IR-MCFC can take place are illustrated in Fig. 1. At the operation temperature of $923 \mathrm{~K}$, the molten carbonate, present in the pores of the anode, can either evaporate as alkali hydroxide and diffuse through the vapor phase toward the catalyst, or it can creep along the metal wall of the anode compartment toward the catalyst. These alkali compounds can then be taken up at various surfaces by adsorption or absorption and can also possibly take part in chemical reactions with the catalyst material.

For an easier interpretation of the experimental results obtained, the following two aspects are discussed in detail: 